on such activities and use secondary documents to compare and contrast student experiences or opportunities for extracurricular activities at other schools.

After studying the history of education in the South, I hope that students are better equipped to ask complex questions pertaining to complex issues that can be directed to themselves, and current and future leaders. Historical knowledge gained in this class has provided students with multiple cases of educational reform efforts. How might that knowledge contribute to their understanding and proceed to question the reform efforts that parents, students, and educators face today? How might that knowledge allow them to analyze policies and motivate change in contemporary issues such as funding equity, zero-tolerance policies, charter schools, and vouchers, to name a few? For example, President Ronald Reagan argued that the educational system was ripe with low standards, lack of purpose, and a failure to strive for excellence. And while the federal government argued for educational reform, it scaled back its role in education and shifted the burden of reform to state and local authorities. So throughout the 1980s and 1990s, reform efforts such as zero-tolerance policies, privatization, vouchers, and less funding from the federal government became part of the landscape of schooling. I believe students can take what they have learned in my class in terms of the need to challenge inequality, interrogate, and triangulate sources, and be sensitive to issues of race, gender, and class and become better informed and active citizens in our democracy.

\title{
Reconstructing the Southern Landscape: The History of Education and the Struggle for Civil Rights in Charleston, South Carolina
}

\author{
Fon N. Hale
}

Course: Foundations of Education

Institution: College of Charleston

\footnotetext{
Jon Hale is an assistant professor of educational history at the College of Charleston in South Carolina. He would like to thank Nancy Beadie for the invitation to submit this piece and the other contributors for their insightful feedback and comments. Jon can be reached at halejn@cofc.edu.
} 
The city of Charleston, South Carolina, illustrates how educators can use people- and place-based case studies as pedagogical tools to reconstruct a Southern public and historic landscape. Teaching the Foundations of Education course in the city of Charleston makes the history that frames contemporary educational issues such as (re)segregation more visible. In the wake of the recent tragedy at the historic African Methodist Episcopal (AME) church in Charleston that claimed nine lives at the hands of Dylann Roof, place and local history help make a silent history more pronounced. A history of resistance and an ongoing struggle for freedom is inscribed into Charleston's landscape as much as the colonial and antebellum grandeur that captures the imagination, and dollars, of a thriving tourism industry. The public and historic landscape, in short, is in and of itself an educative space that allows educators and students to disrupt popular narratives by making the invisible more visible. $^{1}$

Teaching the Foundations of Education at the College of Charleston, a historically white public liberal arts college in South Carolina, presents an opportunity to inculcate future educators and liberal arts majors with a nuanced historical perspective on the institution of education and its role in contemporary society. ${ }^{2}$ The Foundations of Education, a course required of all education majors and a general education option in the humanities, utilizes rich archival sources, a historic landscape, place- and people-based case studies, and an overarching concept of "Charleston as classroom" to engage a rich though painful history. It also illustrates the tensions of white faculty members teaching black history to white students in a city that harbors ideologies of racism. As a white faculty member, I make it clear that my degree and research is grounded in this history, which provides an academic level of expertise. Yet, being white, I can never fully understand or speak for a community of color. Therefore, local histories and expertise are utilized to enhance and personalize this history for students. This course is an opportunity to utilize local history to broaden how knowledge is constructed in the classroom so students can understand history from the perspective of those who created it.

The first lesson gleaned from the history of education in Charleston and the Low Country is that the first laws mandated by colonial governments in the American South dictated that education

'The topic of place and the historic landscape of Charleston is discussed in more length in a recent op-ed piece by Jon Hale and Robert Chase, "Where are America's memorials to pain of slavery, black resistance?” July 9, 2015, CNN, http://www.cnn.com/2015/07/03/opinions/hale-and-chase-breaking-the-cycle/.

${ }^{2}$ The College of Charleston, established in 1770 and segregated until 1970, has an enrollment of 12,000 , which is approximately 90 percent white, 8 percent African American, and 2 percent Latino/a or Asian American. 
was an exclusive right. To illustrate this point, the course covers the Stono Rebellion, the largest colonial era slave uprising, which occurred on September 9, 1739. On this date, a group of slaves organized outside Charleston, robbed a store that served local plantations, killed the owner, armed themselves, and marched toward Spanish Florida, as Spain had recently offered freedom to the enslaved subjects of the British crown. Those of the Stono Rebellion did not make it to their Florida destination, and Low Country planters crushed the revolutionaries that same afternoon. But the insignias of freedom printed on banners communicated a powerful message that literacy was a dangerous tool. Local planters speculated that slaves read the news that announced the Spanish declaration of freedom to those enslaved by the British. South Carolina planters reacted by passing a law forbidding the education of enslaved communities. ${ }^{3}$

Resources and time are often lacking to conduct fieldwork at the actual site of the rebellion, which is modestly demarcated by a lone historic marker on rural Johns Island. Instead, students are first assigned to read the secondary sources on the rebellion by Peter Wood and Jack Schuler. Students also examine the antiliteracy laws of 1740 that constitute the foundation of the "slave codes," specifically the passage that states "[A]ll and every person and persons whatsoever, who shall hereinafter teach or cause any slave or slaves to be taught, to write, or shall use or employ any slave as a scribe in any manner of writing whatsoever, hereafter taught to write, every such person and persons, shall, for every such offense, forfeit the sum of one hundred pounds current money." This demonstrates how the codes sought to regulate, control, and suppress the activities of black communities across the South through education. Compared with the Old Deluder Satan Act of 1642, the Massachusetts act that required education for the purposes of religious instruction, the prohibitive act passed in South Carolina illustrates a historic truth that education during the colonial era was used both as a means of liberation and for extensive control. This historic and dialectical tension is central to the foundations and history of education,

\footnotetext{
${ }^{3}$ Peter Wood, "The Stono Rebellion and Its Consequences," in Black Majority: Negroes in Colonial Soutb Carolina from 1670 through the Stono Rebellion (New York: Knopf, 1974), 308-30. For a complete history, see Jack Shuler, Calling Out Liberty: The Stono Slave Rebellion and the Universal Struggle for Human Rights Jackson: University Press of Mississippi, 2009); and Mark E. Smith, ed., Stono: Documenting and Interpreting a Soutbern Slave Revolt (Columbia: University of South Carolina Press, 2005), xiii-xiv. For a good classroom primary resource, see http://nationalhumanities center.org/pds/becomingamer/peoples/text4/stonorebellion.pdf.

${ }^{4}$ Wood, Black Majority, 277-82; Schuler, Calling Out Liberty. The Teaching American History website often provides excellent primary sources aligned with state standards, in this case South Carolina, http://www.teachingushistory.org/ ttrove/1740slavecode.htm.
} 
and making its history visible frames the nature and purpose of the course.

Though slave codes prohibited the education of African Americans, clandestine educational efforts persisted, and a small, though meaningful, minority of slaves learned the tools of literacy. ${ }^{5}$ The ongoing drive for literacy provided the foundation for freed slaves to establish a system of education after Reconstruction. The establishment of a public school system in the South, as is well known, began with enslaved communities that universally equated freedom with literacy and the newly elected black elected officials that politicized this agenda during Reconstruction. Robert Smalls, the enslaved boatman in Charleston who heroically delivered the Confederate warship the CSS Planter to Union lines in May 1862, illustrates the local connection between Charleston and the larger struggle for a quality education. Once he returned to South Carolina after the Civil War, Smalls was elected to represent his district in the state legislature and, later, the United States Congress. Smalls and his contemporaries, including Hiram Revel and John Lynch of Mississippi, constituted the first black caucus ever elected to Congress. In the spirit of Frederick Douglass, these nineteenth-century lawmakers reconstructed the South by ensuring that South Carolina and her sister Confederate states reentered the Union by promising, for the first time in Southern history, a public system of education. ${ }^{6}$

The case of Robert Smalls makes this history more visible, which influences the way we think of this history and how this information is disseminated to the public and our students. Students are asked to locate the historic marker erected to Robert Smalls in 2012 in downtown Charleston, which is conveniently located within walking distance of campus. Students are asked to take a photograph next to the marker and post it to our online discussion board. Here, students also place Robert Smalls in historic context by drawing on James Anderson, Christopher

\footnotetext{
${ }^{5}$ Bernard Powers, Black Charlestonians: A Social History, 1822-1885 (Fayetteville: University of Arkansas Press, 1994), 52-56. For a full history on the phenomenon of literacy acquisition during slavery, see Heather A. Williams, Self-Taught: African American Education in Slavery and Freedom (Chapel Hill: University of North Carolina Press, 2005).

'Powers, Black Cbarlestonians, 93-94. For a complete history on Robert Smalls, see Edward A. Miller, Jr., Gullab Statesman: Robert Smalls from Slavery to Congress, 18391915 (Columbia: University of South Carolina Press, 1995). For the history of formerly enslaved communities establishing a system of education, see James D. Anderson, The Education of Blacks in the South, 1860-1935 (Chapel Hill: University of North Carolina Press, 1988); Christopher M. Span, From Cotton Field to Scboolbouse: African American Education in Mississippi, 1862-1875 (Chapel Hill: University of North Carolina Press, 2009); Eric Foner, Reconstruction: America's Unfinished Revolution, 1863-1877 (New York: Harper \& Row, 1988), 96-99; and Henry Bullock, $A$ History of Negro Education in the South: From 1619 to the Present (Cambridge, MA: Harvard University Press, 1967).
} 
Span, and Heather Williams. Students then reflect upon why the architects of public education, including the Civil War hero Robert Smalls, have only recently been commemorated with a simple historic marker, which is made more curious in comparison to the Confederate Monument, erected in 1932 for a much higher cost to the city, which is less than two hundred feet away.

African Americans in South Carolina undertook the important work of building schools, which unfolded in a heated ideological debate between advocates of a vocational education and those who proposed a college preparatory curriculum. The infamous debate is inscribed in several ways into the Charleston historic landscape. The American Missionary Association founded the Avery Normal Institute in Charleston in 1865. The school, first run by local Charlestonians Thomas and Francis Cardoza, epitomized a classical liberal arts curriculum that facilitated access to higher education and professional development for African Americans. Avery's mission was closely aligned with W. E. B. Du Bois's concept of the "Talented Tenth," which sought to educate the upper echelons of black society to become civil, political, and economic leaders for promoting racial equality in the United States. ${ }^{7}$ Students are assigned this primary source reading by Du Bois and we discuss the reading and its larger history in the actual space of Avery in a carefully preserved nineteenth-century classroom. Students also explore the history of a different school in Charleston that, in contrast to Avery, supported a vocational education. In 1894, the Reverend John L. Dart opened the Charleston Industrial School, which was eventually renamed Burke Industrial School in 1921 (now Burke Middle and High School). Dart envisioned the mission of the long-overdue free public school as an institution of vocational and moral education. The Charleston Colored Industrial School sought to educate young people with technical skills that would help them secure gainful employment in the local economy. The intended curriculum mirrored the vocational or industrial structure that Booker $T$. Washington and other prominent advocates envisioned for black education. Students also read Washington's "Atlanta Compromise Speech" and visit the digital online exhibit about Burke High School created through the College of Charleston's digital history initiative. ${ }^{8}$ When time permits, students also visit Burke High School, read the historic marker outside, and hear

\footnotetext{
${ }^{7}$ For a complete history of the Avery Normal Institute, see Edmund L. Drago, Initiative, Paternalism, and Race Relations: Cbarleston's Avery Normal Institute (Athens: University of Georgia Press, 1990); Powers, Black Charlestonians, 139-57; and W. E. B. Du Bois, "The Talented Tenth," in The Negro Problem: A Series of Articles by Representative Negroes of To-day (Miami, FL: Mnemosyne Printing, 1969[1903]).

${ }^{8}$ Sherman E. Pyatt, Burke High Scbool, 1894-2006 (Charleston, SC: Arcadia Publishing, 2007); Who Is Burke High?: The History of the Burke High School Family
} 
from the principal, currently Maurice Cannon, about the struggles faced by an all-black school. Today, Burke High School remains as the only traditional noncharter public high school in downtown Charleston. As such, this history continues to shape contemporary discussion of public education in Charleston. 9

The ideological dichotomy between the two schools frames a national tension between conceptions of education for social, political, and economic change and education to maintain the status quo that is supported unequally along race and class lines. This tension is the basis for the core class assignment, which is a research-based essay that asks students to identify how the philosophies of Du Bois and Washington are evident in the history of the Avery Normal Institute and Burke High School. Students also draw upon the work of Vanessa Siddle-Walker and Scott Baker to contextualize the larger debate. ${ }^{10}$ As part of their research, students are expected to examine how divergent educational philosophies between the Avery Normal Institute and Burke Industrial School were apparent in their course offerings and extracurricular activities. While the Industrial School provided classes in carpentry and domestic sciences, for instance, Avery emphasized college preparatory classes aimed to train schoolteachers or students entering colleges and universities. They are also asked how teachers and administrators in both schools worked to ensure that students received the best education possible in spite of ideological differences in a segregated context. ${ }^{11}$

Teaching and studying history in Charleston also provides the resources to understand how education was used to combat social,

(Charleston, SC: South Carolina Humanities Society, 2010); R. Scott Baker, Paradoxes of Desegregation: African American Struggles for Educational Equity in Cbarleston, South Carolina, 1926-1972 (Columbia, SC: University of South Carolina Press, 2006); Booker T. Washington, "Atlanta Exposition Speech," in The Booker T. Wasbington Papers, vol. 3, ed. Louis R. Harlan (Urbana, IL: University of Illinois Press, 1974), 583-87; and Jon Hale, "A History of Burke High School in Charleston, South Carolina since 1894," http://dhi.library.cofc.edu/exhibits/show/history_burke_high_school.

${ }^{9}$ Resistance was still a part of the history of this vocational school. Teachers and students at Burke regularly contested institutional discrimination and worked diligently to provide a quality education, which propagated notions of active citizenship and participatory democracy. R. Scott Baker, "Pedagogies of Protest: African American Teachers and the History of the Civil Rights Movement, 1940-1963," Teacbers College Record 113 (2011): 2777-803; and Jon N. Hale, “The Fight Was Instilled in Us': High School Student Activism and the Civil Rights Movement in Charleston, South Carolina," The South Carolina Historical Magazine 114, no. 1 January 2013): 4-28.

${ }^{10}$ Vanessa Siddle-Walker, Their Higbest Potential: An African American Scbool Community in the Segregated South (Chapel Hill: University of North Carolina Press, 1996); Baker, Paradoxes of Desegregation.

"The Avery Normal Institute Collection, the Dart Family papers, the Lois A. Simms papers, and the collection of Eugene Hunt are housed at the Avery Research Center for African American History and Culture, College of Charleston. Dr. Patricia Lessane, Georgette Mayo, Debra Wright, Dr. Mary Battle, Aaron Spelbring, and Daron Calhoun have been instrumentally helpful in locating records. 
political, and economic inequality. People-based case studies, as noted, inform this history and provide the content, sources, and space within the historical landscape to further illustrate the dichotomy between education for social change and control, as well as the use of space in the public commemoration of this history. Local educator and civil rights legend Septima P. Clark illustrates the historic intersection of education, resistance, and politics. Under the oppressive weight of Jim Crow, Septima Clark, born in 1898 in Charleston, led black educators in the push to provide a quality education in spite of legal barriers. When the city of Charleston refused to hire black teachers, the local branch of the National Association for the Advancement of Colored People (NAACP), with the assistance of Clark, organized to overturn the law, which they did in 1919. In a lifelong commitment to civil rights work, Clark later served as a mentor to Rosa Parks well before her defiant stand in Montgomery. Clark also helped founded the Citizenship Schools on nearby Johns Island, an adult education program that provided the literacy skills needed to pass discriminatory voting policies in South Carolina. Firmly committed to justice, Clark's contract was not renewed after she listed her affiliation with the "subversive" NAACP in 1956. ${ }^{12}$

Clark, interestingly enough, was born across the street from the building that houses the College of Charleston. Students are shocked to learn her house is now a fraternity house with no marker that commemorates her first home, thus a silenced reminder that the history of civil rights is often invisible. Similar to the assignment on Robert Smalls, students are asked to postulate how the city remembers its civil rights history. Students are also encouraged to visit the first Citizenship School, which is still standing on Johns Island. Hurricane Hugo in 1989, however, destroyed the building, and only the foundation and brick frame remains. Clark's records are kept at the Avery Research Center, and as a graduate of Avery and a key leader in the civil rights movement, Clark's records are also used in the core research paper.

One other example provides another avenue to connect place- and people-based case studies to a significant national history. Charleston

${ }^{12}$ For a fuller history of Septima Clark's work at the Avery Institute and her work as an educator in Charleston and the Low Country, see Katherine Mellen Charron, Freedom's Teacber: the Life of Septima Clark (Chapel Hill: University of North Carolina Press, 2012); Septima Poinsette Clark with Legette Blythe, Ecbo in My Soul (New York: Dutton, 1962); and Septima Poinsette Clark and Cynthia Stokes Brown, eds., Ready from Witbin: Septima Clark and the Civil Rights Movement (Navarro, CA: Wild Trees Press, 1996). On a larger discussion of women and education in South Carolina, see Valinda Littlefield, "Teaching Survival and Combat Strategies during the Jim Crow Era: Ruby Middleton Forsythe and Fannie Phelps Adams," in Soutb Carolina Women: Their Lives and Times, eds. Marjorie J. Spruill, Valinda W. Littlefield, and Joan Marie Johnson (Athens: University of Georgia Press, 2010). 
became an integral site in the NAACP's legal strategy to dismantle de jure desegregation in the nationally and internationally celebrated Brown v. Board of Education (1954) decision. While the Low Country was guided by the principle of "separate but equal" as established by the Supreme Court, the education white administrators provided was impeccably separate but far from equal. ${ }^{13}$ The Briggs $v$. Elliot (1952) case was one of the five lawsuits that were combined under the Brown case. The case began in 1948 when the Reverend Joseph A. DeLaine and local parents of Clarendon County filed suit for adequate transportation to the local segregated school they attended. In 1950, with the support of the NAACP, the plaintiffs refiled their case, surpassing transportation and asking for equal educational opportunities in Clarendon County. Thurgood Marshall, the lead NAACP attorney in the Brown case and protégé of Charles Hamilton Houston, argued this case in Charleston, where Judge Waties Waring, in a dissenting opinion, ruled that "segregation is per se inequality." In building upon the work of other cases used in class, students read Waring's dissenting vote in the Briggs decision and, when time and space permits, the class visits the courtroom in which the case was heard. Moreover, students read the oral history of Millicent Brown, the first student to desegregate the presecondary education system in South Carolina, to illustrate that desegregation did not achieve equality. ${ }^{14}$

${ }^{13}$ On the history and significance of the Brown decision, see Richard Kluger, Simple 7ustice: The History of Brown v. Board of Education and Black America's Struggle for Equality (New York: Vintage Books, 2004); Mark Tushnet, The NAACP's Legal Strategy against Segregated Education (Chapel Hill: University of North Carolina Press, 2004); James T. Patterson, Brown v. Board of Education: A Civil Rights Milestone and Its Troubled Legacy (New York: Oxford University Press, 2001); Jack M. Balkin, "Brown v. Board of Education: A Critical Introduction" in What Brown v. Board of Education Should Have Said: The Nation's Top Legal Experts Rewrite America's Landmark Civil Rigbts Decision, ed. Jack M. Balkin (New York: New York University Press, 2001); Peter Irons, fim Crow's Children: The Broken Promise of the Brown Decision (New York: Penguin Books, 2004); and Michael J. Klarman, Brown v. Board of Education and the Civil Rights Movement: Abridged Edition of from fim Crow to Civil Rights: The Supreme Court and the Struggle for Racial Equality (New York: Oxford University Press, 2007).

${ }^{14}$ Waring as quoted in Tinsley E. Yarbrough, $A$ Passion for fustice: 7 . Waties Waring and Civil Rights (New York: Oxford University Press, 1987), 196 (emphasis is original). See also Orville Vernon Burton, Beatrice Burton, and Simon Appleford, "Seeds in Unlikely Soil: The Briggs $v$. Elliott School Segregation Case," in Toward the Meeting of the Waters: Currents in the Civil Rigbts Movement of Soutb Carolina during the Twentieth Century, ed. Winfred B. Moore, Jr. and Orville Vernon Burton (Columbia: University of South Carolina Press, 2008), 176-200; and Baker, Paradoxes of Desegregation, 87-107. Though the NAACP lost the case and South Carolina continued to equalize its public school system to avoid desegregation, local activism supported a swelling grassroots movement that sustained the push for a quality education and established legal precedent behind the monumental Brown decision. On the experiences of desegregation, see Millicent Brown, interview with the author, November 29, 2011. 
A predominantly white student body (9 percent of the College of Charleston is African American) favorably reviews this particular course offering. Evaluations support the idea that students find the course and this approach to history and education intellectually stimulating and it fosters interest in the content area. ${ }^{15}$ To historians of education, this should come as no surprise. Teaching the history of education privileges and cultivates a different historical perspective that is essential in developing a critical viewpoint and consciousness. It should also come as no surprise that some white students feel that race is discussed too much or do not see the value in "black history." This leads to an institutional critique and an inherent contradiction. My whiteness and my role in teaching a silenced history perpetuate the history of excluding students of color and relegating knowledge production to whites who do not reflect the demographics of the surrounding area. Yet, until the gates are thrown open, so to speak, white educators must broaden access by expanding how history (and what history) is taught. Whiteness does not have to preclude a radical critique and critical consciousness. Teaching this history has the potential to introduce and critically frame major debates and ongoing tension in the community around issues of quality education. This history frames recent tragedies at the AME church and it continues to inform ongoing in education. The resegregation of our schools and the tension with privatization through charter schools illustrate deep-seated problems. The Foundations of Education course provides an opportunity for students to read the local historic landscape as a text at the same time they are able to manipulate it to imagine solutions to national challenges.

${ }^{15}$ Evaluations from fourteen sections of this course taught since the fall of 2011, which include an 84.9 percent $(n=342 / 403)$ response rate, were exemplary. The mean rating for the statement, "I found this course intellectually challenging and stimulating" was $4.71 / 5$, for the question "This course increased my interest in the subject," the mean rating was $4.51 / 5$. Both scores are higher than the institutional average. 